\title{
Whole Genome Analysis of Human Rotaviruses Reveals Single Gene Reassortant Rotavirus Strains in Zambia
}

\author{
Wairimu M. Maringa ${ }^{1}$, Julia Simwaka ${ }^{2}$, Peter N. Mwangi ${ }^{1}$, Evans M. Mpabalwani ${ }^{3}$, Jason M. Mwenda ${ }^{4}$, \\ M. Jeffrey Mphahlele ${ }^{5}$, Mapaseka L. Seheri ${ }^{6}$ and Martin M. Nyaga ${ }^{1, *(\mathbb{D}}$
}

1 Next Generation Sequencing Unit, Division of Virology, Faculty of Health Sciences, University of the Free State, Bloemfontein 9300, South Africa; makena96wairimu@gmail.com (W.M.M.); MwangiPN@ufs.ac.za (P.N.M.)

2 Virology Laboratory, Department of Pathology and Microbiology, University Teaching Hospital, Adult and Emergency Hospital, Lusaka 10101, Zambia; juliachibumbya@gmail.com

3 Department of Paediatrics and Child Health, School of Medicine, University of Zambia, Ridgeway, Lusaka RW50000, Zambia; evans.mpabalwani@unza.zm

4 World Health Organization, Regional Office for Africa, Brazzaville P.O. Box 06, Congo; mwendaj@who.int

5 Office of the Deputy Vice Chancellor for Research and Innovation, The North-West University, Potchefstroom 2351, South Africa; jeffrey.mphahlele@nwu.ac.za

6 Diarrhoeal Pathogens Research Unit, Faculty of Health Sciences, Sefako Makgatho Health Sciences University, Pretoria 0204, South Africa; mapaseka.seheri@smu.ac.za

* Correspondence: NyagaMM@ufs.ac.za; Tel.: +27-514-019-158

check for updates

Citation: Maringa, W.M.; Simwaka, J.; Mwangi, P.N.; Mpabalwani, E.M.; Mwenda, J.M.; Mphahlele, M.J.; Seheri, M.L.; Nyaga, M.M. Whole Genome Analysis of Human Rotaviruses Reveals Single Gene Reassortant Rotavirus Strains in Zambia. Viruses 2021, 13, 1872. https://doi.org/10.3390/v13091872

Academic Editor: Susana Guix

Received: 17 August 2021

Accepted: 15 September 2021

Published: 18 September 2021

Publisher's Note: MDPI stays neutral with regard to jurisdictional claims in published maps and institutional affiliations.

Copyright: (c) 2021 by the authors. Licensee MDPI, Basel, Switzerland. This article is an open access article distributed under the terms and conditions of the Creative Commons Attribution (CC BY) license (https:// creativecommons.org/licenses/by/ $4.0 /)$.
Abstract: Rotarix ${ }^{\circledR}$ vaccine was implemented nationwide in Zambia in 2013. In this study, four unusual strains collected in the post-vaccine period were subjected to whole genome sequencing and analysis. The four strains possessed atypical genotype constellations, with at least one reassortant genome segment within the constellation. One of the strains (UFS-NGS-MRC-DPRU4749) was genetically and phylogenetically distinct in the VP4 and VP1 gene segments. Pairwise analyses demonstrated several amino acid disparities in the VP4 antigenic sites of this strain compared to that of Rotarix ${ }^{\circledR}$. Although the impact of these amino acid disparities remains to be determined, this study adds to our understanding of the whole genomes of reassortant strains circulating in Zambia following Rotarix ${ }^{\circledR}$ vaccine introduction.

Keywords: rotavirus; whole genome; genotype constellation; intergenogroup reassortment; amino acid; Rotarix ${ }^{\circledR}$

\section{Introduction}

Group A rotavirus (RVA), a widespread and infectious pathogen that causes dehydrating diarrhea, particularly in children under five years of age, was estimated to have caused approximately 128,000 deaths in 2016. A greater percentage of these deaths (approximately 105,000 ) occurred in sub-Saharan Africa [1]. The significance of RVA burden of disease led to the development of prophylactic vaccines. In that regard, the World Health Organization (WHO) recommended the use of rotavirus vaccines globally [2]. Four WHO-prequalified rotavirus vaccines $\left(\right.$ Rotarix $^{\circledR}$, RotaTeq $^{\circledR}, \operatorname{ROTAVAC}^{\circledR}$, and ROTASIIL ${ }^{\circledR}$ ) are currently in use in 110 countries worldwide as of 5 April 2021 [3]. The two-dose monovalent vaccine Rotarix ${ }^{\circledR}$ (RV1; GlaxoSmithKline Biologicals, Belgium) consists of a single human G1P[8] strain [2]. In sub-Saharan Africa, Rotarix ${ }^{\circledR}$ is used in countries such as Kenya, Mauritania, Namibia, Niger, and Zimbabwe [3]. This vaccine was introduced in Lusaka, Zambia in 2012 as a pilot project and then rolled out nation-wide in 2013 [4,5]. Vaccine coverage in Zambia in 2019 was at 90\% [6].

Rotaviruses contain 11 segments of double-stranded RNA (dsRNA) that encodes six structural viral proteins (VP1-VP4, VP6-VP7) and five and/or six non-structural proteins (NSP1-NSP5/6) [7]. A mature RVA particle comprises an inner core (VP2), which is surrounded by VP1 and VP3, a middle layer (VP6) and an outer layer (VP7) with spikes 
of the VP4 protruding from the outer layer [7]. The antigenicity of the outer proteins, VP7 and VP4, is used to classify RVA into G-types (glycoprotein) and P-types (proteasesensitive), respectively [7]. Since they are targets of neutralizing antibodies that may provide serotype-specific and/or cross-protective immunity, these two proteins are considered critical for vaccine development [8]. Further, a whole genome based genotyping system was established by the Rotavirus Classification Working Group (RCWG), whereby specific genotypes are assigned to the 11 segments of RVA. This system established three human RVA genogroups exhibiting the Wa-like (G1-P[8]-I1-R1-C1-M1-A1-N1-T1-E1-H1), DS-1-like (G2-P[4]-I2-R2-C2-M2-A2-N2-T2-E2-H2), or the AU-1-like (G3-P[9]-I3-R3-C3-M3A3-N3-T3-E3-H3) constellations $[9,10]$.

Due to the segmented genome of RVA, it is common for reassortment events to occur, which play a key role in generating the genetic diversity of the virus [11]. It is crucial to understand genetic exchange through reassortment, particularly those belonging to the two major genogroups, as well as various evolutionary mechanisms that contribute to genetic diversity. RVA genomes have high rates of mutation and are subject to frequent reassortment events, which are primarily responsible for rotavirus evolution [11-16]. RVA with unusual G-P combinations such as G1P[4], G2P[6], G2P[8], G3P[4], and G8P[4] are known to circulate in human populations as a result of intergenogroup reassortment between co-circulating strains. The G1P[4] and G2P[8] have been shown to circulate among G1P[8] and G2P[4] strains [16-21]. Most human RVA strains possess either a typical Wa-like or DS-1-like constellation and are thought to have an evolutionary fitness advantage that allows them to spread widely and persist in human populations [22,23]. Nevertheless, after the isolation of two naturally occurring intergenogroup reassortants between Walike and DS-1-like in Bangladesh in 1985-1986 [24], RVA strains possessing mixed gene constellations of human and / or animal origin have been documented in various parts of the world [25-34].

RVA strain surveillance based on conventional genotyping of VP7 and VP4 has been conducted in Zambia [35]. Unusual G- and P-combinations such as G1P[6] and G9P[6] were reported in 2011 before Rotarix ${ }^{\circledR}$ was implemented. On the contrary, only the G2P[6] was reported post-vaccine implementation [35]. However, there is a dearth of Zambian whole genome sequence data. Here we report the whole genomes of four intergenogroup reassortant strains identified between 2014 and 2016 during the ongoing RVA surveillance in Zambia, to understand the mechanisms that result in genetic diversity among Zambian RVA post-Rotarix ${ }^{\circledR}$ introduction.

\section{Materials and Methods}

\subsection{Ethics Statement}

Ethical approval was obtained from the Health Sciences Research Ethics Committee (HSREC) at the University of the Free State, Bloemfontein, South Africa (Ethics number UFS-HSD2020/0277/2104).

\subsection{Study Samples}

Stool samples were collected in the post-vaccine period from children who presented with acute gastroenteritis. The demographics and clinical profiles of the children from whom the study samples were taken at Arthur Davidson Children's Hospital (ACDH) in Ndola and University Teaching Hospital (UTH) in Lusaka are shown in Table 1. 
Table 1. Table showing the demographics and clinical profiles of the children from which the study samples were obtained.

\begin{tabular}{|c|c|c|c|c|c|c|c|c|}
\hline Sample ID and Year & Hospital & $\begin{array}{c}\text { The Child's Place } \\
\text { of Residence }\end{array}$ & Sex & Age & $\begin{array}{l}\text { Presenting Illness } \\
\text { Symptoms }\end{array}$ & $\begin{array}{l}\text { Dehydration Status } \\
\text { and Treatment } \\
\text { Administered }\end{array}$ & $\begin{array}{l}\text { Vaccination } \\
\text { Status }\end{array}$ & $\begin{array}{l}\text { Outcome of } \\
\text { Illness }\end{array}$ \\
\hline $\begin{array}{l}\text { UFS-NGS-MRC- } \\
\text { DPRU4749/2014 }\end{array}$ & ACDH Ndola & Chifubu & Female & 5 months & $\begin{array}{c}\text { Diarrhoea for } 4 \text { days } \\
\text { (4 episodes in } 24 \mathrm{~h}) \text {, no } \\
\text { vomiting, temperature of } \\
39^{\circ} \mathrm{C}\end{array}$ & $\begin{array}{l}\text { Moderate } \\
\text { dehydration, treated } \\
\text { with ORS }\end{array}$ & Not vaccinated & Alive \\
\hline $\begin{array}{c}\text { UFS-NGS-MRC- } \\
\text { DPRU13232/2016 }\end{array}$ & ACDH Ndola & Kawama & Male & 7 months & $\begin{array}{l}\text { Diarrhoea for } 3 \text { days } \\
\text { ( } 6 \text { episodes in } 24 \mathrm{~h} \text { ), vomiting } \\
\text { for } 2 \text { days }(4 \text { episodes in } 24 \mathrm{~h} \text { ), } \\
\text { temperature of } 38.2^{\circ} \mathrm{C}\end{array}$ & $\begin{array}{l}\text { Severe dehydration, } \\
\text { treated with IV fluids }\end{array}$ & $\begin{array}{l}\text { Vaccinated } \\
\text { (1 dose })\end{array}$ & Alive \\
\hline $\begin{array}{c}\text { UFS-NGS-MRC- } \\
\text { DPRU13541/2016 }\end{array}$ & ACDH Ndola & Mwange A & Male & 8 months & $\begin{array}{c}\text { Diarrhoea for } 3 \text { days } \\
\text { (8 episodes in } 24 \mathrm{~h} \text { ), vomiting } \\
\text { for } 3 \text { days ( } 3 \text { episodes in } 24 \mathrm{~h} \text { ), } \\
\text { no fever }\end{array}$ & $\begin{array}{l}\text { Severe dehydration, } \\
\text { treated with IV fluids }\end{array}$ & Not vaccinated & Alive \\
\hline $\begin{array}{c}\text { UFS-NGS-MRC- } \\
\text { DPRU13327/2016 }\end{array}$ & UTH Lusaka & Kapata & Male & 20 months & $\begin{array}{l}\text { Diarrhoea for } 1 \text { day } \\
\text { ( } 3 \text { episodes in } 24 \text { h), vomiting } \\
\text { for } 3 \text { days, no fever }\end{array}$ & $\begin{array}{l}\text { No dehydration, } \\
\text { treated with ORS }\end{array}$ & $\begin{array}{l}\text { Vaccinated } \\
\text { (2 doses) }\end{array}$ & Alive \\
\hline
\end{tabular}


The four Zambian strains analyzed in this study were collected from one female and three male children aged between 5-20 months, as part of the ongoing rotavirus surveillance by the WHO/AFRO. The strains demonstrated a sporadic transmission pattern, devoid of any sign of an outbreak infection, as they were identified in different parts of Ndola and Lusaka. Further, clinical information indicated that all the children had diarrhea that lasted between a day and four days, with varying frequencies. Similarly, three children presented with two to three days of intermittent vomiting, and two children presented with fever. There were two cases of severe dehydration and one case of moderate dehydration because of diarrhea and vomiting. Two of the four children had been vaccinated, while the other two were not vaccinated. However, all the strains were detected post-Rotarix ${ }^{\circledR}$ vaccine implementation (2014-2016). No mortality resulted due to illness, as all children fully recovered.

Thereafter, the samples were screened for presence of RVA antigen using the ProSpecT ${ }^{\mathrm{TM}}$ Rotavirus Microplate Assay Kit (Oxoid limited, Basingstoke, Hampshire, UK) at the Virology laboratory in Lusaka, Zambia. The samples were then sent to the Diarrhoeal Pathogens Research unit (DPRU), a WHO Regional Reference Laboratory (Pretoria, South Africa) as part of the annual rotavirus surveillance conducted by the WHO-Regional Office for Africa. The samples were first conventionally genotyped at the DPRU before being shipped to the University of the Free State, Next Generation Sequencing unit (UFS-NGS) for whole genome sequencing and analysis. Four RVA strains from a total of 133 were seen to be reassortant strains after whole genome analysis which formed the basis of this study. To address two Terms of Reference between WHO and UFS-NGS, phylogenetic analysis was performed on all strains, and the possible antigenic disparities between Rotarix ${ }^{\circledR}$, global reference strains and one distinct study strain was assessed.

\subsection{Extraction of Double-Stranded RNA and cDNA Synthesis}

Viral double-stranded RNA was extracted and purified using a MinElute ${ }^{\circledR}$ gel extraction kit (Qiagen, Hilden, Germany) according to already established methods [33,36]. Thereafter, the integrity of purified RNA was determined by electrophoresis on $1 \% \mathrm{TBE}$ agarose gel stained with ethidium bromide (Sigma-Aldrich, Saint Louis, MO, USA). Before proceeding with synthesis of complementary DNA (cDNA), the purified dsRNA was first quantified on a Biodrop $\mu$ Lite platform (Biochrom, Cambridge, UK). Samples with a 1.8-2.2 absorbance ratio were considered pure for further processing [37]. A Maxima H Minus Double Stranded cDNA kit (Thermo Fisher Scientific, Waltham, MA, USA) was used in the synthesis of cDNA, according to manufacturer's instructions with minor modifications. The variations were captured in the UFS-NGS SOP as follows: denaturation of dsRNA was performed at $95{ }^{\circ} \mathrm{C}$ for five minutes and first strand synthesis was carried out at $50{ }^{\circ} \mathrm{C}$ for two hours. The generated cDNA was later purified using an MSB ${ }^{\circledR}$ Spin PCRapace purification kit (Stratec, Invitek molecular, Berlin, Germany).

\subsection{DNA Library Preparation and Illumina ${ }^{\circledR}$ Sequencing}

A Nextera ${ }^{\circledR}$ XT DNA library preparation kit (Illumina ${ }^{\circledR}$, San Diego, CA, USA) was utilized to construct a DNA library according to the manufacturer's instructions. This process involved fragmenting DNA and subsequent addition of dual barcodes to the DNA fragments. Agencourt AMPure magnetic beads (Beckman Coulter, Indianapolis, Indiana, USA) were used to purify the barcoded libraries while simultaneously selecting for an average insert of $300 \mathrm{bp}$ (range 200-400 bp). Subsequently, the libraries were validated and quantified prior to sequencing on a 2100 Bioanalyzer platform (Agilent Technologies, Santa Clara, CA, USA) and the Qubit ${ }^{\mathrm{TM}} 3.0$ fluorometer (Invitrogen, Carlsbad, CA, USA), respectively. The validated and quantified libraries were pooled and whole genome sequencing was performed on an Illumina ${ }^{\circledR}$ MiSeq platform using a V3 MiSeq reagent kit (Illumina ${ }^{\circledR}$, San Diego, CA, USA) for 600 cycles to generate $2 \times 301$ bp paired reads. A 5\% PhiX DNA control spike-in was used. 


\subsection{Genome Assembly}

Sequence reads obtained from the Illumina ${ }^{\circledR}$ MiSeq platform in FASTQ format were first trimmed and subsequently assembled using Geneious ${ }^{\circledR}$ Prime 2019.2.1 (https: / / www. geneious.com/; accessed 5 April 2021) [38]. Genome assembly comprised both reference mapping as well as de novo assembly.

\subsection{Identification of Genotype Constellations}

The genotype of each of the 11 genome segments of the four Zambian RVA strains were identified on the Virus Pathogen Resource (ViPR), an online bioinformatics database and analysis resource for virological research [39]. The Basic Local Alignment Search Tool (BLAST) was also utilized as a complementary tool for genotype identification [40].

\subsection{Phylogenetic Analysis}

Reference sequences were compiled using BLAST as well as the Virus Variation Resource hosted by the National Centre for Biotechnology Information (NCBI) [40,41]. Multiple alignments were made for each gene using the MAFFT plugin in Geneious ${ }^{\circledR}$ Prime version 2019.2.1 (https:/ / www.geneious.com/; accessed 5 April 2021) and MUSCLE algorithm that is present in MEGA $6[38,42,43]$. Pairwise nucleotide and amino acid sequence identity matrices were calculated using the $p$-distance algorithm in MEGA 6 [43]. A maximum likelihood tree was constructed for each genome segment. Substitution models that best fit the data were selected based on corrected Akaike Information Criterion (AICc) in MEGA 6 [44]. The models used in this study were: GTR+G+I (VP1), TN93+G (VP2), GTR+I (VP3 and NSP1), T92+G+I (VP4 and VP7), T92+G (VP6, NSP2, NSP4, and NSP5), and TN93+I (NSP3). Branch support was estimated with 1000 bootstrap replicates [45].

\subsection{Protein Modelling}

Protein modelling was performed using the SWISS MODEL online server (SWISSMODEL (expasy.org)) [46,47]. The RVA spike protein databank structure, 2dwr.1, was selected from the SWISS MODEL template library and had an X-ray diffraction resolution value of $2.50 \AA$. The stereochemical quality of the protein structure was assessed using the Structure Assessment feature in SWISS MODEL. The protein structure was modified and visualised using PyMOL (http:/ / www.pymol.org/; accessed 5 April 2021) [48].

\section{Results}

\subsection{Genotyping Based on Whole Genome Constellations}

Following Illumina ${ }^{\circledR}$ MiSeq sequencing, complete or nearly complete nucleotide sequences for each of the 11 genes of the four study strains were obtained. The contig lengths and number of reads after assembly are shown in Table 2. The strains were named as RVA/Human-wt/ZMB/UFS-NGS-MRC-DPRU13232/2016/G1P[8], RVA/Human-wt/ ZMB/UFS-NGS-MRC-DPRU13541/2016/G1P[8], RVA/Human-wt/ZMB/UFS-NGS-MRCDPRU13327/2016/G2P[4], and RVA/Human-wt/ZMB/UFS-NGS-MRC-DPRU4749/2014/ G2P[8] according to the guidelines for the uniformity of RVA by the RCWG, henceforth referred to as UFS-NGS-MRC-DPRU13232, UFS-NGS-MRC-DPRU13541, UFS-NGS-MRCDPRU13327, and UFS-NGS-MRC-DPRU4749, respectively. 


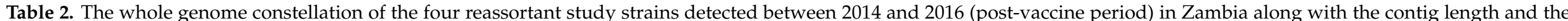
number of reads mapped to each contig.

\begin{tabular}{|c|c|c|c|c|c|c|c|c|c|c|c|c|}
\hline Strain & & VP7 & VP4 & VP6 & VP1 & VP2 & VP3 & NSP1 & NSP2 & NSP3 & NSP4 & NSP5 \\
\hline \multirow[t]{3}{*}{ UFS-NGS-MRC-DPRU13232 } & Genotype & G1 & $\mathrm{P}[8]$ & I1 & $\mathrm{R} 1$ & $\mathrm{C} 1$ & M1 & $\mathrm{A} 1$ & N2 & $\mathrm{T} 1$ & E1 & $\mathrm{H} 1$ \\
\hline & Contig length & 1062 & 2359 & 1356 & 3301 & 2717 & 2591 & 1567 & 1059 & 1074 & 750 & 644 \\
\hline & Reads mapped to contig & 21,238 & 4523 & 14,997 & 87,349 & 52,209 & 52,222 & 26,784 & 53,976 & 30,125 & 25,306 & 21,366 \\
\hline \multirow[t]{3}{*}{ UFS-NGS-MRC-DPRU13541 } & Genotype & G1 & $\mathrm{P}[8]$ & I1 & R1 & $\mathrm{C} 1$ & M1 & A1 & N2 & T1 & E1 & H1 \\
\hline & Contig length & 1063 & 2359 & 1352 & 3301 & 2729 & 2591 & 1567 & 1059 & 1074 & 750 & 663 \\
\hline & Reads mapped to contig & 33,485 & 10,936 & 62,838 & 108,961 & 79,014 & 134,489 & 80,109 & 33,007 & 36,184 & 34,457 & 12,638 \\
\hline \multirow[t]{3}{*}{ UFS-NGS-MRC-DPRU4749 } & Genotype & G2 & $\mathrm{P}[8]$ & I2 & $\mathrm{R} 2$ & $\mathrm{C} 2$ & M2 & $\mathrm{A} 2$ & N2 & $\mathrm{T} 2$ & E2 & $\mathrm{H} 2$ \\
\hline & Contig length & 1062 & 2360 & 1356 & 3302 & 2684 & 2591 & 1569 & 1059 & 1066 & 750 & 815 \\
\hline & Reads mapped to contig & 1445 & 4513 & 2302 & 6738 & 4388 & 5214 & 2315 & 1063 & 1268 & 916 & 471 \\
\hline \multirow[t]{3}{*}{ UFS-NGS-MRC-DPRU13327 } & Genotype & G2 & $\mathrm{P}[4]$ & $\mathrm{I} 2$ & R2 & $\mathrm{C} 2$ & M2 & A2 & N1 & $\mathrm{T} 2$ & E2 & $\mathrm{H} 2$ \\
\hline & Contig length & 1062 & 2359 & 1354 & 3298 & 2684 & 2591 & 1566 & 1059 & 1066 & 751 & 798 \\
\hline & Reads mapped to contig & 24,446 & 51,762 & 23,311 & 67,839 & 53,795 & 60,905 & 25,147 & 11,048 & 20,338 & 13,618 & 13,618 \\
\hline
\end{tabular}

The Wa-like genogroup is represented in green, while the DS-1-like genogroup is represented in red. 
The genotype constellations demonstrated that the strains were generated through reassortment between Wa-like and DS-1-like strains. Applying the whole genome-based genotyping system [9,10], UFS-NGS-MRC-DPRU13232, UFS-NGS-MRC-DPRU13541, UFSNGS-MRC-DPRU13327, and UFS-NGS-MRC-DPRU4749 had the following constellations: G1-P[8]-I1-R1-C1-M1-A1-N2-T1-E1-H1, G1-P[8]-I1-R1-C1-M1-A1-N2-T1-E1-H1, G2-P[4]I2-R2-C2-M2-A2-N1-T2-E2-H2 and G2-P[8]-I2-R2-C2-M2-A2-N2-T2-E-H2, respectively (Table 2) and were therefore considered mono-reassortants, as shown on the bolded genotypes. Strain UFS-NGS-MRC-DPRU13232 and UFS-NGS-MRC-DPRU13541 possessed Walike constellations except for the N2 NSP2 genotype. Strain UFS-NGS-MRC-DPRU13327 and UFS-NGS-MRC-DPRU4749 possessed DS-1-like constellations with the exception of N1 NSP2 genotype and P[8] VP4 genotype, respectively.

The 11 genes of the two Wa-like Zambian strains (UFS-NGS-MRC-DPRU13232 and UFS-NGS-MRC-DPRU13541) exhibited a high level of sequence conservation with $>99 \%$ sequence identity to each other. On the other hand, the two DS-1-like Zambian strains (UFSNGS-MRC-DPRU13327 and UFS-NGS-MRC-DPRU4749) exhibited high sequence identity (>97\%) in the VP7, VP6, VP2, NSP1, NSP3, and NSP5 genes, whereas lower identities were observed in the VP4, VP1, VP3, NSP2, and NSP4 genes $(82.7 \%, 91.0 \%, 87.9 \%, 82.7 \%$, and 90.9\%, respectively) (Supplementary data 1).

\subsection{Phylogenetic and Sequence Analysis}

To understand the genetic relationship of the four Zambian strains with global stains, a phylogenetic tree was resolved for each of the 11 gene segments. For the designation of lineages in the VP7, VP4, and VP1 trees, closely related strains as well as strains on the respective lineages, were selected from the GenBank using previously published articles as reference [49-54].

\subsubsection{Phylogenetic Analysis of the VP7 Genes (G1 and G2)}

Reference RVA strains utilized in this analysis segregated into the known seven G1 lineages and five G2 lineages [51,52]. A multiple sequence alignment and phylogenetic analysis of the VP7 genes of the four study strains showed that the Zambian G1 strains (UFSNGS-MRC-DPRU13232 and UFS-NGS-MRC-DPRU13541) clustered with other reference strains in lineage G1 I (Figure 1). Lineage G1 I was comprised of African and Asian strains identified between 2003-2017 with maximum nucleotide (nt) and amino acid (aa) identities ranging from 96.8-99.1\% and 97.5-99.7\% with the two Zambian G1 strains (Figure 1; Supplementary data 1). Among the two Zambian G1 strains, the nt and aa identity was $100 \%$. On the other hand, the Zambian G2 strains (UFS-NGS-MRC-DPRU4749 and UFSNGS-MRC-DPRU13327 clustered in lineage G2 IV along with strains from Asia and Africa with nt (aa) identities of 93.8-99.6\% (92.6-100\%) (Figure 1; Supplementary data 1). A nt and aa similarity of $97.8 \%$ and $98.5 \%$ was shared between the two Zambian G2 strains (Supplementary data 1). 


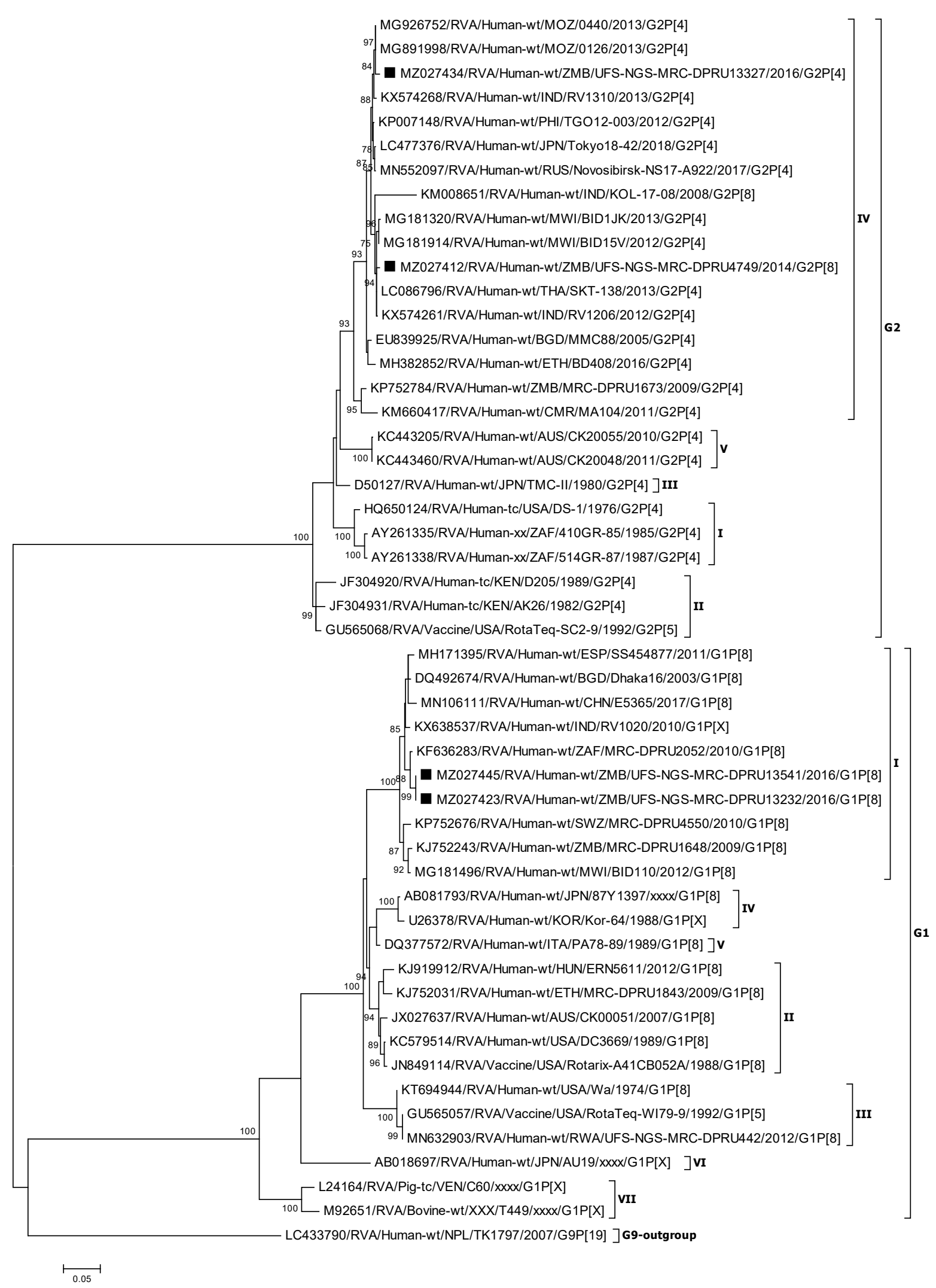

Figure 1. VP7 phylogenetic tree of the Zambian G1 and G2 strains indicated by black squares along with representative strains. Phylogenetic analysis was conducted using the maximum likelihood method with bootstrap values of 1000 replicates. The scale at the bottom indicates the number of nucleotide substitutions per site. Percent values of bootstrap values greater than or equal to 70 is indicated on the branch nodes. 


\subsubsection{Phylogenetic Analysis of the VP4 Genes (P[4] and P[8])}

The VP4 P[8] and P[4] Zambian strains were compared to global selected reference strains that belong to the already established four P $[4]$ and four P $[8]$ lineages $[51,53]$. Based on the VP4 phylogenetic tree, two of the Zambian P[8] strains (UFS-NGS-MRCDPRU13232, and UFS-NGS-MRC-DPRU13541) co-clustered in lineage P[8] III and shared nt (aa) identity of $99.8 \%$ and $99.9 \%$, respectively (Figure 2; Supplementary data 1). Lineage P[8] III consisted of predominantly African strains (Cameroon, Togo, South Africa, and Zimbabwe) that showed nt (aa) identities of 97.6-99.0\% (98.7-99.2\%) to the two Zambian $\mathrm{P}$ [8] strains. The vaccine strain, RVA/Vaccine/USA/Rotarix-A41CB052A/1988/G1P[8], clustered in lineage P[8] I with nt (aa) identities of $90.3-90.4 \%$ (93.9-94.1\%) to the two aforementioned Zambian P[8] strains.

Interestingly, UFS-NGS-MRC-DPRU4749 clustered separately from the other lineages, including that containing Rotarix ${ }^{\circledR}$ (Lineage P[8] I; nt 84.9\%), as well as the most common lineage globally (Lineage P[8] III) [55] that contained the other Zambian P[8] strains (Figure 2; Supplementary data 1). This strain was closest to a South African strain that clustered in lineage P[8] III, RVA/Human-wt/ZAF/MRC-DPRU2035/2010/G1P[8] with nt (aa) identity of $90.2 \%$ (92.8\%) (Supplementary data 1).

For the P[4] Zambian strain, UFS-NGS-MRC-DPRU13327 clustered with lineage P[4] IV strains and exhibited maximum nt (aa) similarity of $99.6 \%(99.2 \%)$ and $99.4 \%(99.1 \%)$ to a Mozambican strain and an Indian strain, respectively.

\subsubsection{Comparison of the VP4 Antigenic Epitopes of Zambian G2P [8] to Rotarix ${ }^{\circledR}$}

The pattern of aa substitution occurring in $\mathrm{P}[8]$ strains in each lineage, including the phylogenetically distinct Zambian strain UFS-NGS-MRC-DPRU4749 that was seen to be phylogenetically distinct, was analyzed relative to that of Rotarix ${ }^{\circledR}$. It was observed that there were 26 fully conserved aa residues. Overall, most of the aa changes in the P[8] strains relative to Rotarix ${ }^{\circledR}$ were displayed in the VP8* (8-1 and 8-3) region (Figure 3). Lineage I P [8] strains possessed the same aa at all positions. While lineage II P[8] strains had five aa substitutions from Rotarix ${ }^{\circledR}$ (N195D, S125N, S131R, N135D, and I388L), the I388L substitution occurred only in one of the lineage II P[8] strains. Lineage III P[8] strains had six aa substitutions (E150D, N194G, N195G, S125N, S131R, and N135D) relative to Rotarix ${ }^{\circledR}$. However, the substitution N195G was present in only one of the two lineage III $P[8]$ strains. Lineage IV P[8] strains also known as OP354-like [56-58] had seven aa changes (N192D, N194T, N195S, N113D, S131R, I388L, and E459D). 


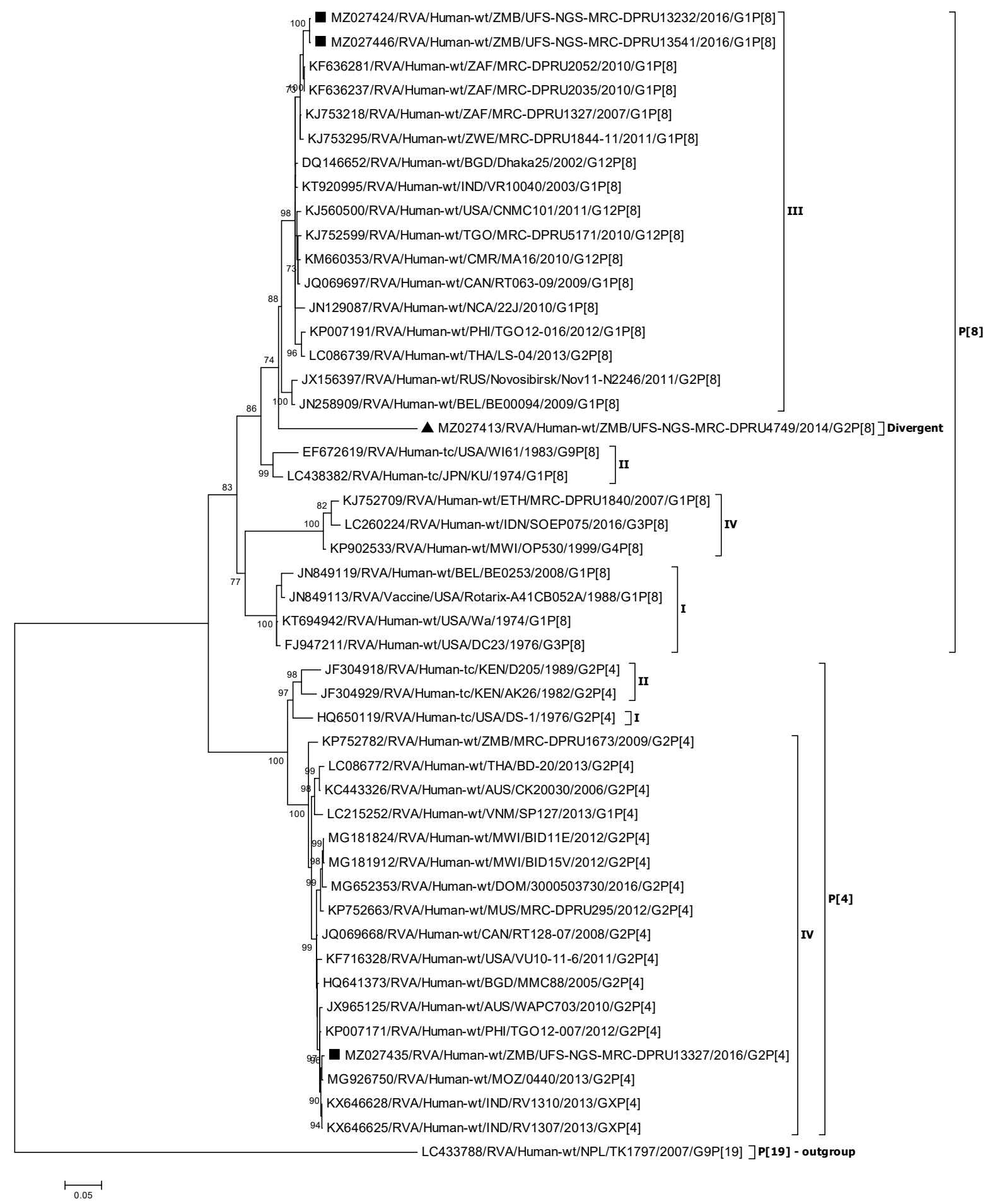

Figure 2. VP4 phylogenetic tree of the Zambian P[4] and P[8] strains indicated by black squares along with representative strains. Strain UFS-NGS-MRC-DPRU4749, indicated by a black triangle, is a divergent strain. Phylogenetic analysis was conducted using the maximum likelihood method with bootstrap values of 1000 replicates. The scale at the bottom indicates the number of nucleotide substitutions per site. Percent values of bootstrap values greater than or equal to 70 is indicated on the branch nodes. 


\begin{tabular}{|c|c|c|c|c|c|c|c|c|c|c|c|c|c|c|c|c|c|c|c|c|c|c|c|c|c|c|c|c|c|c|c|}
\hline & & \multicolumn{30}{|c|}{ Neutralisation epitopes } \\
\hline & & \multirow{2}{*}{\multicolumn{9}{|c|}{$8-1$}} & \multirow{2}{*}{\multicolumn{2}{|c|}{${ }^{8-2}$}} & \multirow{2}{*}{\multicolumn{7}{|c|}{$8-3$}} & \multicolumn{2}{|c|}{$8-4$} & \multicolumn{7}{|c|}{$5-1$} & \multirow{2}{*}{\multicolumn{3}{|c|}{$\begin{array}{lllll}5-2 & 5-3 & 5-4 & 5-5 \\
\end{array}$}} \\
\hline & & $\cdot 0$ & & & & & & & & & & & & & & & & & & & & & & & & & & & & & \\
\hline Strains & Lineage & 100 & 1461 & $148 \quad 1$ & $50 \quad 188$ & 3190 & 192 & 19319 & 34195 & 196 & 180 & 183 & 113 & 114 & 115116 & 6125 & 1311 & 132133 & 3135 & & $88 \quad 89$ & 384 & 3863 & & 393394 & 34398 & & 441 & & 459 & \\
\hline JN849113/RVA/Vaccine/USA/Rotarix-A41CB052A/1988/G1P[8] & & & & & & & & & & & & & & & & & & & & & $\mathrm{N}$ & & & & & & & & & & \\
\hline RVA/Human-wt/ZMB/UFS-NGS-MRC-DPRU4749/2014/G2P[8] & Divergent & & & D & & & & & G & & & & D & A & & $\mathrm{N}$ & $\mathrm{R}$ & & D & & & & & & & & & & & & \\
\hline KT694942/RVA/Human-wt/USA/Wa/1974/G1P[8] & I & & & & & & & & & & & & & & & & & & & & & & & & & & & & & & \\
\hline Fj947211/RVA/Human-wt/USA/DC23/19 & I & & & & & & & & & & & & & & & & & & & & & & & & & & & & & & \\
\hline & II & & & & & & & & D & & & & & & & $\mathrm{N}$ & $\mathrm{R}$ & & D & & & & $\mathrm{L}$ & & & & & & & & \\
\hline & II & & & & & & & & D & & & & & & & $\mathrm{N}$ & & & D & & & & & & & & & & & & \\
\hline DQ146652/RVA/Human-wt/BGD/Dhaka25/2002/G12P[ & III & & & D & & & & & G & & & & & & & $\mathrm{N}$ & $\mathrm{R}$ & & $\mathrm{D}$ & & & & & & & & & & & & \\
\hline JN258909/RVA/Human-wt/BEL/BE00094/2009/G1P[8] & III & & & D & & & & G & G & & & & & & & $\mathrm{N}$ & $\mathrm{R}$ & & D & & & & & & & & & & & & \\
\hline KJ752709/RVA/Human-wt/ETH/MRC-DPRU1840/2007/G1P[8] & IV & & & & & & D & $\mathrm{T}$ & $\mathrm{s}$ & & & & D & & & & $\mathrm{R}$ & & & & & & $\mathrm{L}$ & & & & & & & D & \\
\hline KP902533/RVA/Human-wt/MWI/OP530/1999/G4P[8] & IV & & & & & & D & $\mathrm{T}$ & $\mathrm{s}$ & & & & $\mathrm{D}$ & & & $\mathrm{R}$ & $\mathrm{R}$ & & & & & & $\mathrm{L}$ & & & & & & & D & \\
\hline
\end{tabular}

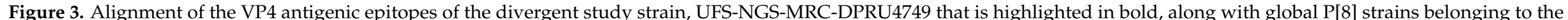

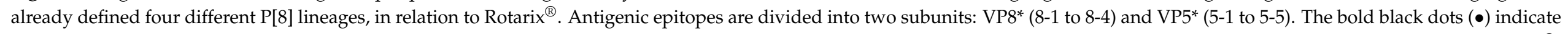

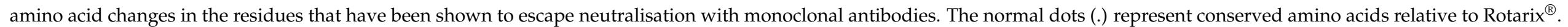


Comparison of the divergent Zambian P[8] strain against Rotarix ${ }^{\circledR}$ showed 30 identical aa residues spanning the VP4 antigenic epitopes (Figure 3). Seven aa changes, E150D, N195G, N113D, V115A, S125N, S131R, and N135D, were seen in the study strain relative to Rotarix ${ }^{\circledR}$ (Figure 3). These changes were located on the surface of the protein structure (Figure 4). Analysis of the Zambian P[8] strain relative to two selected strains of the most common lineage, lineage P[8] III [55], identified two aa differences (D113N and A115V).

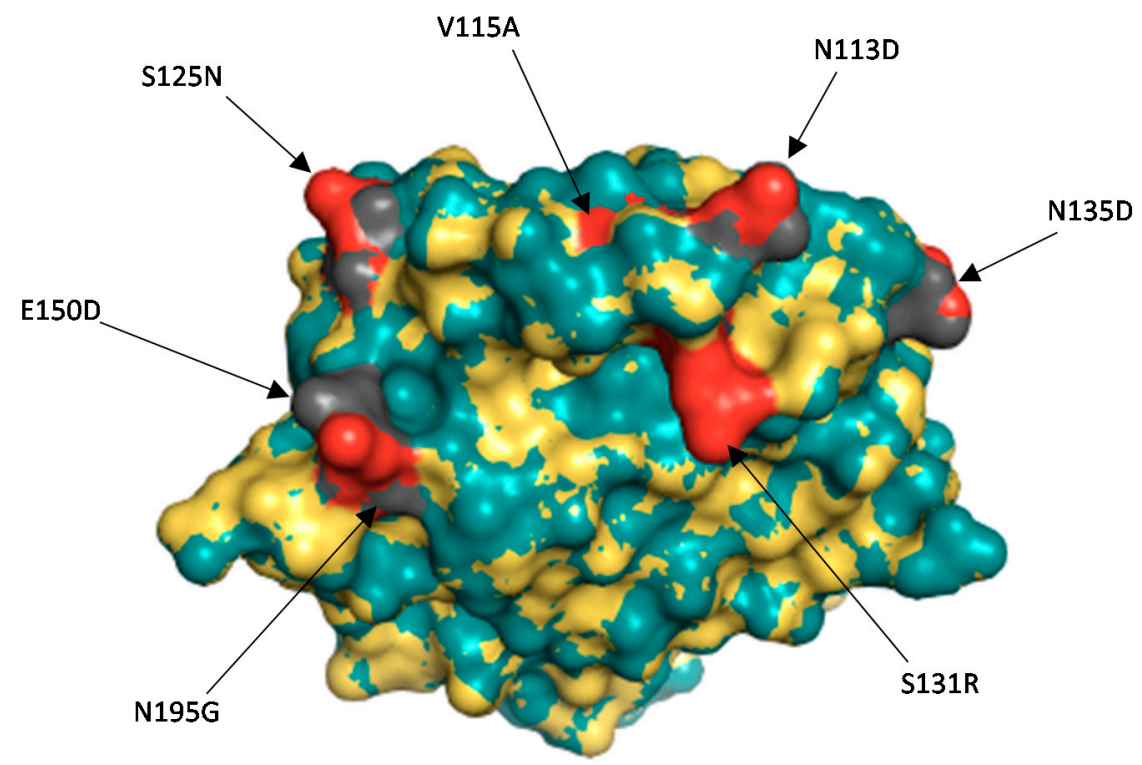

Figure 4. Surface representation of the VP8* protein of Rotarix ${ }^{\circledR}$ and the divergent study strain UFSNGS-MRC-DPRU4749. The superposition of the two structures has the root square mean deviation of $0.048 \AA$. Rotarix ${ }^{\circledR}$ structure is represented by the teal colour whereas the Zambian P[8] strain is indicated in yellow. The red colour represents the amino acid changes observed on the Zambian study strain as compared to Rotarix ${ }^{\circledR}$ vaccine strain in grey.

\subsubsection{Phylogenetic Analysis of the VP1 Gene}

The two Zambian Wa-like strains (UFS-NGS-MRC-DPRU13232 and UFS-NGS-MRCDPRU13541) clustered among R1 African strains. The two strains shared highest nt (aa) similarity of 99.4\% (99.4-99.7\%) with South African strains RVA/Human-wt/ZAF/MRCDPRU2030/2010/G1P[8] and RVA/Human-wt/ZAF/MRC-DPRU2052/2010/G1P[8] (Figure 5; Supplementary data 1).

Doan et al. [52] established five lineages for global R2 strains. More recently, Agbemabiese et al. [49] proposed 14 lineages for R2 strains which included human and animal RVA strains. Based on this, one of the two DS-1-like Zambian strains, UFS-NGS-MRCDPRU13327, clustered in lineage R2 V that mainly comprised of African strains (Figure 5). This strain displayed maximum nt (aa) identities of $99.4 \%(99.7 \%)$ with strains from Zimbabwe and Mozambique (Supplementary data 1). In the VP1 phylogenetic tree, a cluster of strains within the R2 genotype could not be classified under any lineage according to the established designations $[49,52]$ and were therefore named "undefined".

Strain UFS-NGS-MRC-DPRU4749 clustered independently (Figure 5), and shared the highest similarity to RVA/Human-wt/IND/NIV1416591/2014/G9P[4] that clustered in Lineage R2 V, with nt (aa) identities of 93\% (96.6\%) (Supplementary data 1). 


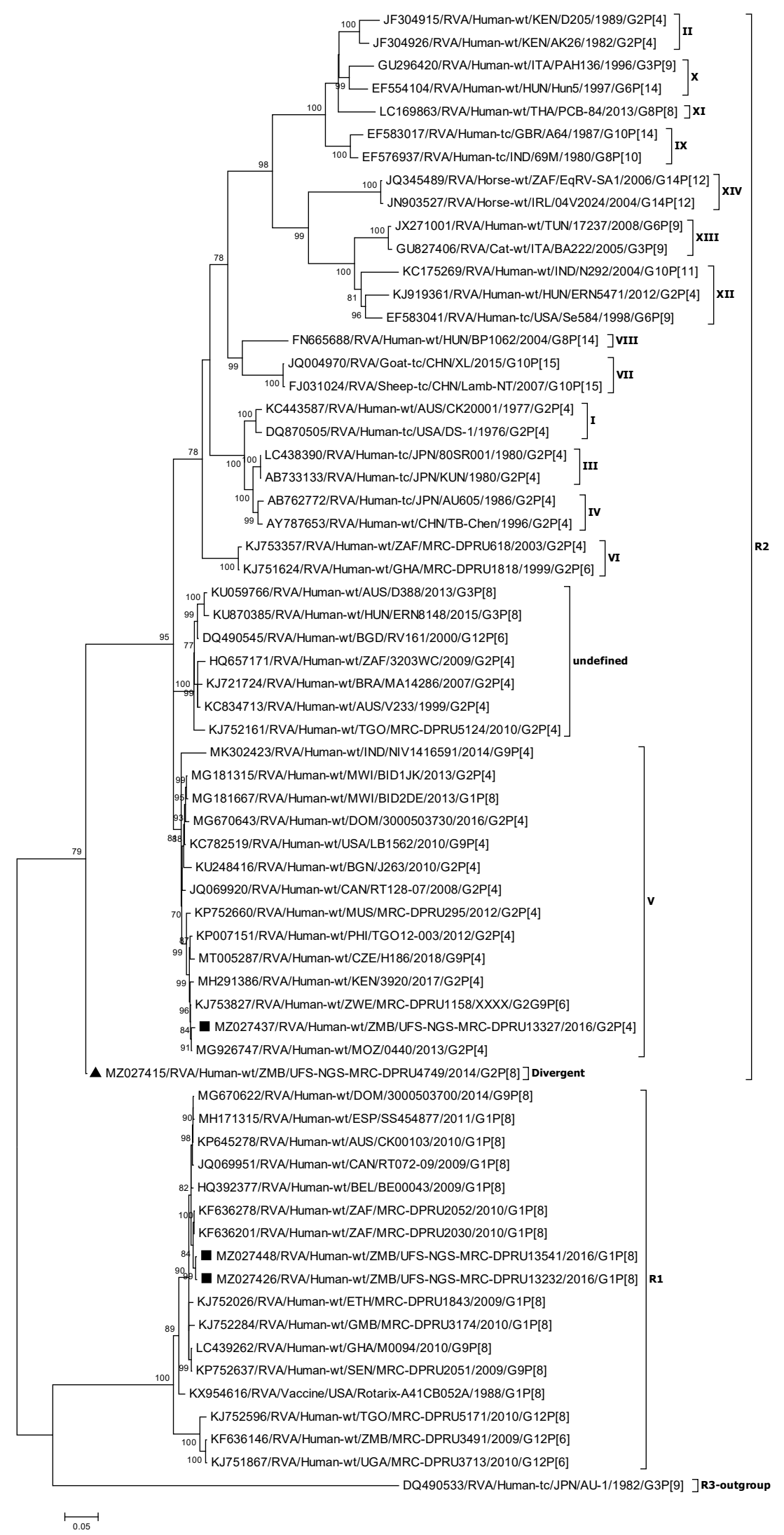

Figure 5. VP1 phylogenetic tree of the Zambian R1 and R2 strains indicated by black squares along with representative Strain UFS-NGS-MRC-DPRU4749, indicated by a black triangle is a divergent strain. Phylogenetic analysis was conducted using the maximum likelihood method with bootstrap values of 1000 replicates. The scale at the bottom indicates the number of nucleotide substitutions per site. Percent values of bootstrap values greater than or equal to 70 is indicated on the branch nodes. 


\subsubsection{Phylogenetic Analysis of the VP6, VP2 and VP3 Genes}

The VP6, VP2, and VP3 genes of the four Zambian strains clustered among African strains. The VP6 genes of Wa-like strains UFS-NGS-MRC-DPRU13232 and UFS-NGS-MRCDPRU13541 displayed maximum nt identities (97.7-98.1\%) with the VP6 genes of the South African strain RVA/Human-wt/ZAF/MRC-DPRU2052/2010/G1P[8] (Supplementary data 1). Phylogenetically, the two Wa-like Zambian strains co-clustered in lineage I1 (Supplementary data 2). On the other hand, the DS-1-like Zambian strains (UFS-NGS-MRCDPRU4749 and UFS-NGS-MRC-DPRU13327) clustered separately under lineage I2 among strains identified in Malawi and Mozambique with nt and aa identities of $99.7-99.9 \%$ and 99.7-100\% (Supplementary data 1; Supplementary data 2).

The VP2 genes of the two Wa-like Zambian strains co-clustered in lineage $\mathrm{C} 1$ and exhibited highest nt identity of $98.7 \%$ with the South African strain RVA/Human-wt/ZAF/MRCDPRU2052/2010/G1P[8] and Zimbabwean strain RVA/Human-wt/ZWE/MRC-DPRU184411/2011/G1P[8], whereas the two Zambian DS-1-like strains clustered in lineage C2, exhibiting maximum nt (aa) identities of 98.8-99.5\% (99.4-100\%) with VP2 genes of Malawian and Mozambican strains (Supplementary data 1; Supplementary data 2). Like the VP2 gene, the VP3 genes of the two Wa-like Zambian strains co-clustered in lineage M1 that consisted predominantly of African strains. Highest nt (aa) identities of 99.199.2\% (98.8-99.0\%) was observed to the Zimbabwean strain RVA/Human-wt/ZWE/MRCDPRU1844-11/2011/G1P[8] and the South African strain RVA/Human-wt/ZAF/MRCDPRU2052/2010/G1P[8]. The VP3 genes of the two Zambian DS-1-like strains were in two different clusters within the M2 lineage. UFS-NGS-MRC-DPRU13327 showed highest nt similarity (99.4\%) with Mozambican strain RVA/Human-wt/MOZ/0440/2013/G2P[4] whereas the other DS-1-like Zambian strain, UFS-NGS-MRC-DPRU4749, was closest to Malawian strains with nt (aa) identities of 99.3-99.6\% (99.0-99.4\%) (Supplementary data 1; Supplementary data 2).

\subsubsection{Phylogenetic Analysis of the NSP1-NSP5 Genes}

Phylogenetically, the NSP1, NSP3, NSP4, NSP4, and NSP5 genes of the two Zambian Wa-like strains (UFS-NGS-MRC-DPRU13232 and UFS-NGS-MRC-DPRU13541) coclustered in lineages A1, T1, E1 and H1, respectively, whereas the two DS-1-like Zambian strains (UFS-NGS-MRC-DPRU4749 and UFS-NGS-MRC-DPRU13327) clustered distant from each other in lineages A2, T2, E2 and H2 (Supplementary data 2). For the NSP2 gene, UFS-NGS-MRC-DPRU13327 clustered in N1, while UFS-NGS-MRC-DPRU4749, UFS-NGS-MRC-DPRU13232 and UFS-NGS-MRC-DPRU13541 co-clustered in lineage N2 (Supplementary data 2).

The NSP1 and NSP4 genes of UFS-NGS-MRC-DPRU13232 and UFS-NGS-MRCDPRU13541 fell into clusters predominantly comprised of African strains, and were closest to the strains, RVA/Human-wt/ZWE/MRC-DPRU1844-11/2011/G1P[8] and RVA/Humanwt/MRC-DPRU1544/2010/G1P[8], with nt (aa) identities of 98.0-98.5\% (97.1-98.6\%) (Supplementary data 1; Supplementary data 2). In contrast, the NSP3 and NSP5 genes of the two Zambian G1P[8] strains displayed the highest nt (99.0-99.1\%) and aa (98.5-99.7\%) identities to Brazilian strains (Supplementary data 1; Supplementary data 2).

For the DS-1-like Zambian strains, UFS-NGS-MRC-DPRU4749 clustered closely with Malawian strains in the NSP1, NSP3, NSP4, and NSP5 genes, displaying nt (aa) identities of $99.2-99.3 \%$ (98.6-98.85), 99.4-99.7\% (99.7-100\%), 98.9\% (99.4\%) and, $98.6-99.2 \%$ $(99.0-99.5 \%)$, respectively (Supplementary data 1; Supplementary data 2). UFS-NGS-MRCDPRU13327, on the other hand, was closest related to Mozambican strain RVA/Humanwt/MOZ/0440/2013/G2P[4] in the NSP1, NSP3, and NSP5 genes with maximum nt (aa) identities of $99.5 \%(99.4 \%), 99.6 \%$ (99.7\%), and 99.7\% (99.5\%) in those respective genes (Supplementary data 1; Supplementary data 2). For the NSP4 gene, UFS-NGS-MRC-DPRU13327 clustered among Asian strains and exhibited the highest nt (aa) identity of $97.7 \%$ (98.9\%) to strain RVA/Human-wt/IND/RV1206/2012/G2P[4] (Supplementary data 1; Supplementary data 2). 
Based on the NSP2 gene, UFS-NGS-MRC-DPRU13327, UFS-NGS-MRC-DPRU13232 and UFS-NGS-MRC-DPRU13541 were seen to be reassortants. The DS-1-like Zambian strain, UFS-NGS-MRC-DPRU13327, belonged to genotype N1 and clustered among strains from Asia, Oceania, and Europe, with maximum nt (aa) identities of 99.4\% (100\%) and 99.5\% $(99.7 \%)$ to a Russian and Indian strain, respectively (Supplementary data 1; Supplementary data 2). The two Wa-like Zambian strains, UFS-NGS-MRC-DPRU13232 and UFS-NGSMRC-DPRU13541, along with the DS-1-like strain UFS-NGS-MRC-DPRU4749 belonged to genotype N2 and displayed highest nt (aa) similarity of 99.4-99.8\% (98.7-99.7\%) to Malawian strains (Supplementary data 1; Supplementary data 2).

\section{Discussion}

The present study reported on four intergenogroup reassortant strains in Zambia. Whole genome sequencing and analyses demonstrated that the four study strains possessed mixed genotypes in at least one gene segment within the constellation between Wa-like and DS-1-like genogroups, hence were considered intergenogroup reassortant strains. Such reassortant strains have been detected in countries such as Germany, Japan, Lebanon, Malawi, Rwanda, Senegal, South Africa, and Zimbabwe [28,30,34,59-63]. A key observation was made regarding strain UFS-NGS-MRC-DPRU4749. This strain was seen to be phylogenetically distinct in the VP4 gene, as it did not cluster into any of the already defined P[8] lineages [51]. VP4 analysis on BLAST and ViPR showed that UFS-NGS-MRCDPRU4749 possessed a nucleotide variance of almost $10 \%$ to the closest strain. The same observation was made in the VP1 gene, whereby the Zambian strain clustered distinctly from other established R2 lineages proposed by Doan et al. [52] and Agbemabiese et al. [49], with a nucleotide variance of $7 \%$ to the closest strain. Further, the divergent Zambian strain was supported by bootstrap values of $88 \%$ and $79 \%$ at the branching node in the VP4 and VP1 phylogenetic trees, respectively. The large genetic distance to other global strains on both nt and aa level concurred with the distinct clustering seen in the VP4 and VP1 phylogenetic trees, thus strain UFS-NGS-MRC-DPRU4749 can be considered as a divergent strain.

The VP4 spike protein is proteolytically cleaved into VP8* and VP5* subunits by trypsin-like proteases present in the gastrointestinal tract of a host, which in the process activates the rotavirus particle $[64,65]$. The VP5* enables the penetration of the virus by permeabilizing lipid vesicles during infection, while the VP8* is thought to mediate attachment to the host [66-68]. Four (8-1 to 8-4) and five (5-1 to 5-5) epitopes are contained in the VP8* and VP5* subunits, respectively, which are targets for neutralizing monoclonal antibodies [55]. Neutralizing antibodies that target the VP8* neutralize infectivity of the virus by inhibiting attachment, while those directed against VP5* are thought to block membrane penetration $[69,70]$. The VP4 is involved in several important structural and functional roles such as attachment, penetration, and particle maturation. Due to this, the genetic variability is more restricted in human VP4 RVA as compared to the VP7 [7,58,70]. This characteristic is exploited by the current vaccines, Rotarix ${ }^{\circledR}$ which contains a single human G1P[8] and RotaTeq ${ }^{\circledR}$ that contains G1-G4 and a P[8] genotype [71]. Therefore, while the higher genetic variability in the VP7 may compromise immunity induced by vaccines, the VP4 component of vaccines may compensate when a human is infected with a $\mathrm{P}[8]$ strain. In agreement with the observation of low genetic variability in VP4, around $70 \%(26 / 37)$ of the aa residues belonging to the global human P[8] RVA strains, including Zambian strain UFS-NGS-MRC-DPRU4749, were fully conserved when compared to the Rotarix ${ }^{\circledR}$ vaccine strain.

Accumulation of point mutations, along with reassortment and other mechanisms of rotavirus evolution, is a key mechanism that generates genetic diversity in RVA over time [11-15]. Seven aa substitutions were identified in the VP8* (8-1 and 8-3) region when the study strain UFS-NGS-MRC-DPRU4749 was compared against Rotarix ${ }^{\circledR}$. Of the seven, four were seen to be radical in nature (N195G, N113D, S131R, and N135D). With respect to the nature of aa, the N195G substitution resulted in a change in polarity (polar to non-polar) 
whereas N113D, S131R, and N135D resulted in a change in charge (polar neutral to acidic polar negative, polar neutral to basic polar positive, and polar neutral to acidic polar negative, respectively) [72]. One peculiar aa difference was the V115A which occurred only in the study strain. This mutation is considered conservative because the charge and polarity of the aa remained unchanged. It is therefore unlikely that this change would affect protein structure and hydrophobicity $[72,73]$. The impact of such a change on rotavirus transmission and vaccine effectiveness remains to be determined.

\section{Conclusions}

This study lends credence to reassortment being a major evolutionary mechanism in RVA. Since the other three Zambian strains were also collected during the post-vaccine period, the discovery of the phylogenetically and genetically divergent Zambian G2P [8] strain was unexpected. Given that this strain was identified in an unvaccinated child, it remains unclear whether the aa mutations present in the VP4 gene would have a negative impact on the effectiveness of the vaccine. Continuous surveillance of circulating RVA, along with whole genome sequencing and analysis is therefore critical in monitoring the impact of such reassortant strains on children, as well as their impact on effectiveness of current vaccine products.

Supplementary Materials: The following are available online at https:/ /www.mdpi.com/article/10 $.3390 / \mathrm{v} 13091872 / \mathrm{s} 1$, Supplementary data 1: Identity matrices (nucleotide and amino acid) among strains for the VP7, VP4, VP6, VP1, VP2, VP3, NSP1, NSP2, NSP3, NSP4 and NSP5 calculated using the p-distance algorithm in MEGA 6. Supplementary data 2: Additional phylograms containing Figure S1 (VP6), Figure S2 (VP2), Figure S3 (VP3), Figure S4 (NSP1), Figure S5 (NSP2), Figure S6 (NSP3), Figure S7 (NSP4), and Figure S8 (NSP5).

Author Contributions: M.M.N. and J.M.M. conceptualised the main project. M.M.N., J.S., E.M.M., M.J.M., M.L.S. and J.M.M. facilitated obtaining of the samples. W.M.M., P.N.M. and M.M.N. conducted the laboratory experiments. Formal and bioinformatic analysis was executed by W.M.M., P.N.M. and M.M.N. Original draft preparation (writing) was carried out by W.M.M. Review of the drafts was done by all co-authors. M.M.N. supervised the project and sourced for funding. All authors have read and agreed to the published version of the manuscript.

Funding: This research was primarily funded by a WHO grant awarded to M.M.N (agreement number UFS-AGR-000378). Additional grants from the Bill and Melinda Gates Foundation (BMGFOPP1180423_2017), the South African Medical Research Foundation through the Self-Initiated Research grant, the National Research Foundation (NRF-120814) and the Poliomyelitis Research Foundation (PRF-19/16) awarded to M.M.N also supported this research. The views and opinions expressed in this article do not reflect those of the funders and affiliated institutions, but rather those of the authors of this publication.

Institutional Review Board Statement: The study was conducted according to the guidelines of the Declaration of Helsinki and approved by the Health Sciences Research Ethics Committee (clearance number UFS-HSD2020/0277/2104) of the University of the Free State, Bloemfontein, South Africa.

Informed Consent Statement: Consent was waived for patients, as the diarrhoeal stool samples were collected as part of the diagnostic clinical samples when parents took their child to the hospital for clinical management, which did not require written informed consent.

Data Availability Statement: The authors confirm that all data relevant to this study is contained in the article and the supplementary materials. Additionally, sequences generated in this study were deposited in the GenBank under accession numbers MZ027412-MZ027455.

Acknowledgments: We would like to acknowledge the Zambia team for assistance with sample collection. We also thank Kebareng Rakau and Nonkululeko Magagula for their assistance in retrieving the samples at the WHO-RRL (Pretoria, South Africa). Sebotsana Rasebotsa and Milton Mogotsi are duly acknowledged for assistance with laboratory work. Lastly, we express our gratitude to Stephanus Riekert for providing technical ICT support.

Conflicts of Interest: The authors declare no conflict of interest. 


\section{References}

1. Troeger, C.; Khalil, I.A.; Rao, P.C.; Cao, S.; Blacker, B.F.; Ahmed, T.; Armah, G.; Bines, J.E.; Brewer, T.G.; Colombara, D.V.; et al. Rotavirus vaccination and the global burden of rotavirus diarrhoea among children younger than 5 years. JAMA Pediatr. 2018, 172, 958-965. [CrossRef]

2. World Health Organization. Rotavirus vaccines WHO position paper: January 2013-Recommendations. Wkly. Epidemiol. Rec. 2013, 5, 49-64. [CrossRef]

3. International Vaccine Access Centre, John Hopkins Bloomberg School of Public Health. Map. VIEW-hub. Available online: https:/ / view-hub.org/ (accessed on 15 April 2021).

4. Chilengi, R.; Rudd, C.; Bolton, C.; Guffey, B.; Masumbu, P.K.; Stringer, J. Successes, challenges and lessons learned in accelerating introduction of rotavirus immunisation in Zambia. World J. Vaccines 2015, 5, 43-53. [CrossRef]

5. Mpabalwani, E.M.; Simwaka, C.J.; Mwenda, J.M.; Mubanga, C.P.; Monze, M.; Matapo, B.; Parashar, U.D.; Tate, J.E. Impact of rotavirus vaccination on diarrhoeal hospitalisations in children aged $<5$ Years in Lusaka, Zambia. Clin. Infect. Dis. 2016, 62, S183-S187. [CrossRef]

6. World Health Organization. WHO Vaccine-Preventable Diseases: Monitoring System. 2020 Global Summary. 2021. Available online: https://apps.who.int/immunization_monitoring/globalsummary (accessed on 15 April 2021).

7. Estes, M.K.; Greenberg, H.B. Rotaviruses. In Fields Virology, 6th ed.; Knipe, D.M., Howley, P.M., Eds.; Wolters Kluwer Health/Lippincott, Williams and Wilkins: Philadelphia, PA, USA, 2013; pp. 1347-1401.

8. Hoshino, Y.; Kapikian, A.Z. Rotavirus Serotypes: Classification and Importance in Epidemiology, Immunity, and Vaccine Development. J. Health Popul. Nutr. 2000, 18, 5-14. Available online: https://www.jstor.org/stable/23499057 (accessed on 8 April 2021). [PubMed]

9. Matthijnssens, J.; Ciarlet, M.; McDonald, S.M.; Attoui, H.; Bányai, K.; Brister, J.R.; Buesa, J.; Esona, M.D.; Estes, M.K.; Gentsch, J.R.; et al. Uniformity of rotavirus strain nomenclature proposed by the Rotavirus Classification Working Group (RCWG). Arch. Virol. 2011, 156, 1397-1413. [CrossRef] [PubMed]

10. Matthijnssens, J.; Ciarlet, M.; Rahman, M.; Attoui, H.; Bányai, K.; Estes, M.K.; Gentsch, J.R.; Iturriza-Gómara, M.; Kirkwood, C.D.; Martella, V.; et al. Recommendations for the classification of group A rotaviruses using all 11 genomic RNA segments. Arch. Virol. 2008, 153, 1621-1629. [CrossRef] [PubMed]

11. Ghosh, S.; Kobayashi, N. Whole-genomic analysis of rotavirus strains: Current status and future prospects. Future Microbiol. 2011, 6, 1049-1065. [CrossRef]

12. Donker, N.C.; Kirkwood, C.D. Selection and evolutionary analysis in the nonstructural protein NSP2 of rotavirus A. Infect. Genet. Evol. 2012, 12, 1355-1361. [CrossRef] [PubMed]

13. Hoxie, I.; Dennehy, J.J. Intragenic recombination influences rotavirus diversity and evolution. Virus Evol. 2020, 6, 1-16. [CrossRef] [PubMed]

14. Kirkwood, C.D. Genetic and Antigenic Diversity of Human Rotaviruses: Potential Impact on Vaccination Programs. J. Infect. Dis. 2010, 202, S43-S48. [CrossRef]

15. Matthijnssens, J.; Heylen, E.; Zeller, M.; Rahman, M.; Lemey, P.; Van Ranst, M. Phylodynamic analyses of rotavirus genotypes G9 and G12 underscore their potential for swift global spread. Mol. Biol. Evol. 2010, 27, 431-2436. [CrossRef]

16. Ramig, R.F. Genetics of the rotaviruses. Annu. Rev. Microbiol. 1997, 51, 225-255. [CrossRef]

17. Banerjee, A.; Lo, M.; Indwar, P.; Deb, A.K.; Das, S.; Manna, B.; Dutta, S.; Bhadra, U.K.; Bhattacharya, M.; Okamoto, K.; et al. Upsurge and spread of G3 rotaviruses in Eastern India (2014-2016): Full genome analyses reveals heterogeneity within Wa-like genomic constellation. Infect. Genet. Evol. 2018, 63, 158-174. [CrossRef]

18. Doro, R.; Farkas, S.L.; Martella, V.; Banyai, K. Zoonotic transmission of rotavirus: Surveillance and control. Expert Rev. Anti. Infect. Ther. 2015, 13, 1337-1350. [CrossRef]

19. Ghosh, S.; Shintani, T.; Urushibara, N.; Taniguchi, K.; Kobayashi, N. Whole-genomic analysis of a human G1P[9] rotavirus strain reveals intergenogroup reassortment events. J. Gen. Virol. 2012, 93, 1700-1705. [CrossRef]

20. Nyaga, M.M.; Stucker, K.M.; Esona, M.D.; Jere, K.C.; Mwinyi, B.; Shonhai, A.; Tsolenyanu, E.; Mulindwa, A.; Chibumbya, J.N.; Adolfine, H.; et al. Whole-genome analyses of DS-1-like human G2P[4] and G8P[4] rotavirus strains from Eastern, Western and Southern Africa. Virus Genes 2014, 49, 196-207. [CrossRef] [PubMed]

21. Seheri, L.M.; Magagula, N.B.; Peenze, I.; Rakau, K.; Ndadza, A.; Mwenda, J.M.; Weldegebriel, G.; Steele, A.D.; Mphahlele, M.J. Rotavirus strain diversity in Eastern and Southern African countries before and after vaccine introduction. Vaccine 2018, 36, 7222-7230. [CrossRef] [PubMed]

22. Heiman, E.M.; McDonald, S.M.; Barro, M.; Taraporewala, Z.F.; Bar-Magen, T.; Patton, J.T. Group A human rotavirus genomics: Evidence that gene constellations are influenced by viral protein interactions. J. Virol. 2008, 82, 11106-11116. [CrossRef] [PubMed]

23. McDonald, S.M.; Matthijnssens, J.; McAllen, J.K.; Hine, E.; Overton, L.; Wang, S.; Lemey, P.; Zeller, M.; Van Ranst, M.; Spiro, D.J.; et al. Evolutionary Dynamics of Human Rotaviruses: Balancing Reassortment with Preferred Genome Constellations. PLoS Pathog. 2009, 5, e1000634. [CrossRef]

24. Ward, R.L.; Nakagomi, O.; Knowlton, D.R.; McNeal, M.M.; Nakagomi, T.; Clemens, J.D.; Sack, D.A.; Schiff, G.M. Evidence for natural reassortants of human rotaviruses belonging to different genogroups. J. Virol. 1990, 64, 3219-3225. [CrossRef]

25. Cowley, D.; Donato, C.M.; Roczo-Farkas, S.; Kirkwood, C.D. Emergence of a novel equine-like G3P[8] intergenogroup reassortant rotavirus strain associated with gastroenteritis in Australian children. J. Gen. Virol. 2016, 97, 403-410. [CrossRef] 
26. Heylen, E.; Likele, B.B.; Zeller, M.; Stevens, S.; De Coster, S.; Conceição-Neto, N.; Van Geet, C.; Jacobs, J.; Ngbonda, D.; Van Ranst, M.; et al. Rotavirus surveillance in Kisangani, the Democratic Republic of the Congo, reveals a high number of unusual genotypes and gene segments of animal origin in non-vaccinated symptomatic children. PLoS ONE 2014, 9, e100953. [CrossRef]

27. Hoa-Tran, T.N.; Nakagomi, T.; Vu, H.M.; Nguyen, T.T.T.; Takemura, T.; Hasebe, F.; Dao, A.T.H.; Anh, P.H.Q.; Nguyen, A.T.; Dang, A.D.; et al. Detection of three independently-generated DS-1-like G9P[8] reassortant rotavirus A strains during the G9P[8] dominance in Vietnam, 2016-2018. Infect. Genet. Evol. 2020, 80, 104194. [CrossRef] [PubMed]

28. Jere, K.C.; Chaguza, C.; Bar-zeev, N.; Lowe, J.; Peno, C.; Kumwenda, B. Emergence of double- and triple-gene reassortant G1P[8] rotaviruses possessing a DS-1-like backbone after rotavirus vaccine introduction in Malawi. J. Virol. 2018, 92, e01246-17. [CrossRef]

29. Katz, E.M.; Esona, M.D.; Betrapally, N.S.; De La Cruz De Leon, L.A.; Neira, Y.R.; Rey, G.J.; Bowen, M.D. Whole-gene analysis of inter-genogroup reassortant rotaviruses from the Dominican Republic: Emergence of equine-like G3 strains and evidence of their reassortment with locally-circulating strains. Virology 2019, 534, 114-131. [CrossRef]

30. Komoto, S.; Tacharoenmuang, R.; Guntapong, R.; Ide, T.; Tsuji, T.; Yoshikawa, T.; Tharmaphornpilas, P.; Sangkitporn, S.; Taniguchi, K. Reassortment of Human and Animal Rotavirus Gene Segments in Emerging DS-1-Like G1P[8] Rotavirus Strains. PLoS ONE 2016, 11, e0148416. [CrossRef]

31. Luchs, A.; da Costa, A.C.; Cilli, A.; Komninakis, S.C.V.; Carmona, R.D.C.C.; Morillo, S.G.; Sabino, E.C.; Timenetsky, M.D.C.S.T. First Detection of DS-1-like G1P[8] Double-gene Reassortant Rotavirus Strains on The American Continent, Brazil, 2013. Sci. Rep. 2019, 9, 2210. [CrossRef] [PubMed]

32. Maringa, W.M.; Mwangi, P.N.; Simwaka, J.; Mpabalwani, E.M.; Mwenda, J.M.; Peenze, I.; Esona, M.D.; Mphahlele, M.J.; Seheri, M.L.; Nyaga, M.M. Molecular Characterisation of a Rare Reassortant Porcine-Like G5P[6] Rotavirus Strain Detected in an Unvaccinated Child in Kasama, Zambia. Pathogens 2020, 9, 663. [CrossRef] [PubMed]

33. Nyaga, M.M.; Tan, Y.; Seheri, M.L.; Halpin, R.A.; Akopov, A.; Stucker, K.M.; Fedorova, N.B.; Shrivastava, S.; Duncan Steele, A.; Mwenda, J.M.; et al. Whole-genome sequencing and analyses identify high genetic heterogeneity, diversity and endemicity of rotavirus genotype P[6] strains circulating in Africa. Infect. Genet. Evol. 2018, 63, 79-88. [CrossRef]

34. Nyaga, M.M.; Jere, K.C.; Esona, M.D.; Seheri, M.L.; Stucker, K.M.; Halpin, R.A.; Akopov, A.; Stockwell, T.B.; Peenze, I.; Diop, A.; et al. Whole genome detection of rotavirus mixed infections in human, porcine and bovine samples co-infected with various rotavirus strains collected from sub-Saharan Africa. Infect. Genet. Evol. 2015, 31, 321-334. [CrossRef] [PubMed]

35. Simwaka, J.C.; Mpabalwani, E.M.; Seheri, M.; Peenze, I.; Monze, M.; Matapo, B.; Parashar, U.D.; Mufunda, J.; Mphahlele, J.M.; Tate, J.E.; et al. Diversity of rotavirus strains circulating in children under five years of age who presented with acute gastroenteritis before and after rotavirus vaccine introduction, University Teaching Hospital, Lusaka, Zambia, 2008-2015. Vaccine 2018, 36, 7243-7247. [CrossRef] [PubMed]

36. Potgieter, A.C.; Page, N.A.; Liebenberg, J.; Wright, I.M.; Landt, O.; van Dijk, A.A. Improved strategies for sequence-independent amplification and sequencing of viral double-stranded RNA genomes. J. Gen. Virol. 2009, 90, 1423-1432. [CrossRef] [PubMed]

37. Desjardins, P.; Conklin, D. NanoDrop Microvolume Quantitation of Nucleic Acids. J. Vis. Exp. 2010, 45, e2565. [CrossRef] [PubMed]

38. Kearse, M.; Moir, R.; Wilson, A.; Stones-Havas, S.; Cheung, M.; Sturrock, S.; Buxton, S.; Cooper, A.; Markowitz, S.; Duran, C.; et al. Geneious Basic: An integrated and extendable desktop software platform for the organisation and analysis of sequence data. Bioinformatics 2012, 28, 1647-1649. [CrossRef] [PubMed]

39. Pickett, B.E.; Sadat, E.L.; Zhang, Y.; Noronha, J.M.; Squires, R.B.; Hunt, V.; Liu, M.; Kumar, S.; Zaremba, S.; Gu, Z.; et al. ViPR: An open bioinformatics database and analysis resource for virology research. Nucleic Acids Res. 2012, 40, D593-D598. [CrossRef]

40. Sayers, E.W.; Beck, J.; Bolton, E.E.; Bourexis, D.; Brister, J.R.; Canese, K.; Comeau, D.C.; Funk, K.; Kim, S.; Klimke, W.; et al. Database resources of the National Centre for Biotechnology Information. Nucleic Acids 2021, 49, D10-D17. [CrossRef]

41. Hatcher, E.L.; Zhdanov, S.A.; Bao, Y.; Blinkova, O.; Nawrocki, E.P.; Ostapchuck, Y.; Schaffer, A.A.; Brister, J.R. Virus Variation Resource-improved response to emergent viral outbreaks. Nucleic Acids Res. 2017, 45, D482-D490. [CrossRef]

42. Katoh, K.; Standley, D.M. MAFFT multiple sequence alignment software version 7: Improvements in performance and usability. Mol. Biol. Evol. 2013, 30, 772-780. [CrossRef]

43. Tamura, K.; Stecher, G.; Peterson, D.; Filipski, A.; Kumar, S. MEGA 6: Molecular evolutionary genetics analysis version 6.0. Mol. Biol. Evol. 2013, 30, 2725-2729. [CrossRef]

44. Guindon, S.; Gascuel, O. A simple, fast, and accurate algorithm to estimate large phylogenies by maximum likelihood. Syst. Biol. 2003, 52, 696-704. [CrossRef]

45. Felsenstein, J. Confidence Limits on Phylogenies: An approach using the bootstrap. Evolution 1985, 39, 783-791. [CrossRef] [PubMed]

46. Bienert, S.; Waterhouse, A.; De Beer, T.A.P.; Tauriello, G.; Studer, G.; Bordoli, L.; Schwede, T. The SWISS-MODEL Repository-new features and functionality. Nucleic Acids Res. 2017, 45, D313-D319. [CrossRef]

47. Waterhouse, A.; Bertoni, M.; Bienert, S.; Studer, G.; Tauriello, G.; Gumienny, R.; Heer, F.T.; de Beer, T.A.P.; Rempfer, C.; Bordoli, L.; et al. SWISS-MODEL: Homology modelling of protein structures and complexes. Nucleic Acids Res. 2018, 46, W296-W303. [CrossRef]

48. DeLano, W.L. Pymol: An open-source molecular graphics tool. CCP4 Newsl. Protein Crystallogr. 2002, 40, 82-92. 
49. Agbemabiese, C.A.; Nakagomi, T.; Damanka, S.A.; Dennis, F.E.; Lartey, B.L.; Armah, G.E.; Nakagomi, O. Sub-genotype phylogeny of the non-G, non-P genes of genotype 2 Rotavirus A strains. PLoS ONE 2019, 14, e0217422. [CrossRef] [PubMed]

50. Aida, S.; Nahar, S.; Paul, S.K.; Hossain, M.A.; Kabir, M.R.; Sarkar, S.R.; Ahmed, S.; Ghosh, S.; Urushibara, N.; Kawaguchiya, M.; et al. Whole genomic analysis of G2P[4] human rotaviruses in Mymensingh, north-central Bangladesh. Heliyon 2016, 2, e00168. [CrossRef]

51. Arista, S.; Giammanco, G.M.; De Grazia, S.; Ramirez, S.; Biundo, C.L.; Colomba, C.; Cascio, A.; Martella, V. Heterogeneity and temporal dynamics of evolution of G1 human rotaviruses in a settled population. J. Virol. 2006, 80, 10724-10733. [CrossRef] [PubMed]

52. Doan, Y.H.; Nakagomi, T.; Agbemabiese, C.A.; Nakagomi, O. Changes in the distribution of lineage constellations of G2P[4] Rotavirus A strains detected in Japan over 32 years (1980-2011). Infect. Genet. Evol. 2015, 34, 423-433. [CrossRef] [PubMed]

53. Doan, Y.H.; Nakagomi, T.; Nakagomi, O. Repeated circulation over 6 years of intergenogroup mono-reassortant G2P[4] rotavirus strains with genotype N1 of the NSP2 gene. Infect. Genet. Evol. 2012, 12, 1202-1212. [CrossRef]

54. Gouvea, V.; Lima, R.C.; Linhares, R.E.; Clark, H.F.; Nosawa, C.M.; Santos, N. Identification of two lineages (WA-like and F45-like) within the major rotavirus genotype P[8]. Virus Res. 1999, 59, 141-147. [CrossRef]

55. Zeller, M.; Patton, J.T.; Heylen, E.; De Coster, S.; Ciarlet, M.; Van Ranst, M.; Matthijnssens, J. Genetic analyses reveal differences in the VP7 and VP4 antigenic epitopes between human rotaviruses circulating in Belgium and rotaviruses in Rotarix and RotaTeq. J. Clin. Microbiol. 2012, 50, 966-976. [CrossRef] [PubMed]

56. Cunliffe, N.A.; Gondwe, J.S.; Graham, S.M.; Thindwa, B.D.; Dove, W.; Broadhead, R.L.; Molyneux, M.E.; Hart, C.A. Rotavirus strain diversity in Blantyre, Malawi, from 1997 to 1999. J. Clin. Microbiol. 2001, 39, 836-843. [CrossRef] [PubMed]

57. Nagashima, S.; Kobayashi, N.; Paul, S.K.; Alam, M.M.; Chawla-Sarkar, M.; Krishnan, T. Characterisation of full-length VP4 genes of OP354-like P[8] human rotavirus strains detected in Bangladesh representing a novel P[8] subtype. Arch. Virol. 2009, 154, 1223-1231. [CrossRef] [PubMed]

58. Zeller, M.; Heylen, E.; Damanka, S.; Pietsch, C.; Donato, C.; Tamura, T.; Kulkarni, R.; Arora, R.; Cunliffe, N.; Maunula, L.; et al. Emerging OP354-like P[8] rotaviruses have rapidly dispersed from Asia to other continents. Mol. Biol. Evol. 2015, 32, $2060-2071$. [CrossRef] [PubMed]

59. Giammanco, G.M.; Bonura, F.; Zeller, M.; Heylen, E.; Van Ranst, M.; Martella, V.; Bányai, K.; Matthijnssens, J.; De Grazia, S. Evolution of DS-1-like human G2P[4] rotaviruses assessed by complete genome analysis. J. Gen. Virol. 2014, 95, 91-109. [CrossRef] [PubMed]

60. Mishra, N.; Reslan, L.; El-Husseini, M.; Raoof, H.; Finianos, M.; Guo, C.; Thakkar, R.; Inati, A.; Dbaibo, G.; Lipkin, W.; et al. Full genome characterisation of human G3P[6] and G3P[9] rotavirus strains in Lebanon. Infect. Genet. Evol. 2020, 78, 104133. [CrossRef] [PubMed]

61. Pietsch, C.; Liebert, U.G. Molecular characterisation of different equine-like G3 rotavirus strains from Germany. Infect. Genet. Evol. 2018, 57, 46-50. [CrossRef]

62. Rasebotsa, S.; Uwimana, J.; Mogotsi, M.T.; Rakau, K.; Magagula, N.B.; Seheri, M.L.; Mwenda, J.M.; Mphahlele, M.J.; Sabiu, S.; Mihigo, R.; et al. Whole-genome analyses identifies multiple reassortant rotavirus strains in Rwanda post-vaccine introduction. Viruses 2021, 13, 95. [CrossRef]

63. Thanh, H.D.; Tran, V.T.; Lim, I.; Kim, W. Emergence of human G2P[4] rotaviruses in the post-vaccination era in South Korea: Footprints of multiple interspecies reassortment events. Sci. Rep. 2018, 8, 2-11. [CrossRef]

64. Dormitzer, P.R.; Nason, E.B.; Prasad, B.V.V.; Harrison, S.C. Structural rearrangements in the membrane penetration protein of a non-enveloped virus. Nature 2004, 430, 1053-1058. [CrossRef] [PubMed]

65. Graham, D.Y.; Estes, M.K. Proteolytic enhancement of rotavirus infectivity: Biologic mechanisms. Virology 1980, 101, 432-439. [CrossRef]

66. Denisova, E.; Dowling, W.; LaMonica, R.; Shaw, R.; Scarlata, S.; Ruggeri, F.; Mackow, E.R. Rotavirus capsid protein VP5* permeabilises membranes. J. Virol. 1999, 73, 3147-3153. [CrossRef]

67. Dowling, W.; Denisova, E.; LaMonica, R.; Mackow, E.R. Selective membrane permeabilisation by the rotavirus Vp5* protein is abrogated by mutations in an internal hydrophobic domain. J. Virol. 2000, 74, 6368-6376. [CrossRef]

68. Fiore, L.; Greenberg, H.B.; Mackow, E.R. The VP8 fragment of VP4 is the rhesus rotavirus hemagglutinin. Virology 1991, 181, 553-563. [CrossRef]

69. Ruggeri, F.M.; Greenberg, H.B. Antibodies to the trypsin cleavage peptide VP8 neutralise rotavirus by inhibiting binding of virions to target cells in culture. J. Virol. 1991, 65, 2211-2219. [CrossRef]

70. Trask, S.D.; McDonald, S.M.; Patton, J.T. Structural insights into the coupling of virion assembly and rotavirus replication. Nat. Rev. Microbiol. 2012, 10, 165-177. [CrossRef]

71. Rota Council. Available Rotavirus Vaccine Products-Rotavirus Vaccines Prequalified by WHO. 2020. Available online: https: / / preventrotavirus.org (accessed on 16 April 2021).

72. Betts, M.J.; Russel, R.B. Amino acid properties and consequences of substitutions. In Bioinformatics for Geneticists; John Wiley \& Sons Ltd.: Hoboken, NJ, USA, 2007; pp. 311-342. [CrossRef]

73. Garnier, J.; Osguthorpe, D.J.; Robson, B. Analysis of the accuracy and implications of simple methods for predicting the secondary structure of globular proteins. J. Mol. Biol. 1978, 120, 97-120. [CrossRef] 